\title{
GRK1 Gene
}

National Cancer Institute

\section{Source}

National Cancer Institute. GRK1 Gene. NCI Thesaurus. Code C24739.

This gene is involved in sensory transduction necessary for vision. 